\title{
Acetate Activation in Methanosaeta thermophila: Characterization of the Key Enzymes Pyrophosphatase and Acetyl-CoA Synthetase
}

\author{
Stefanie Berger, Cornelia Welte, and Uwe Deppenmeier \\ Institute for Microbiology and Biotechnology, University of Bonn, Meckenheimer Allee 168, 53115 Bonn, Germany \\ Correspondence should be addressed to Uwe Deppenmeier, udeppen@uni-bonn.de
}

Received 16 May 2012; Accepted 30 June 2012

Academic Editor: Francesca Paradisi

Copyright (C) 2012 Stefanie Berger et al. This is an open access article distributed under the Creative Commons Attribution License, which permits unrestricted use, distribution, and reproduction in any medium, provided the original work is properly cited.

\begin{abstract}
The thermophilic methanogen Methanosaeta thermophila uses acetate as sole substrate for methanogenesis. It was proposed that the acetate activation reaction that is needed to feed acetate into the methanogenic pathway requires the hydrolysis of two ATP, whereas the acetate activation reaction in Methanosarcina sp. is known to require only one ATP. As these organisms live at the thermodynamic limit that sustains life, the acetate activation reaction in Mt. thermophila seems too costly and was thus reevaluated. It was found that of the putative acetate activation enzymes one gene encoding an AMP-forming acetyl-CoA synthetase was highly expressed. The corresponding enzyme was purified and characterized in detail. It catalyzed the ATP-dependent formation of acetylCoA, AMP, and pyrophosphate $\left(\mathrm{PP}_{\mathrm{i}}\right)$ and was only moderately inhibited by $\mathrm{PP}_{\mathrm{i}}$. The breakdown of $\mathrm{PP}_{\mathrm{i}}$ was performed by a soluble pyrophosphatase. This enzyme was also purified and characterized. The pyrophosphatase hydrolyzed the major part of $\mathrm{PP}_{\mathrm{i}}\left(K_{M}=0.27 \pm 0.05 \mathrm{mM}\right)$ that was produced in the acetate activation reaction. Activity was not inhibited by nucleotides or $\mathrm{PP}_{\mathrm{i}}$. However, it cannot be excluded that other $\mathrm{PP}_{\mathrm{i}}$-dependent enzymes take advantage of the remaining $\mathrm{PP}_{\mathrm{i}}$ and contribute to the energy balance of the cell.
\end{abstract}

\section{Introduction}

Methanogenic archaea are of high ecological importance as they are responsible for closure of the global carbon cycle and production of the greenhouse gases $\mathrm{CO}_{2}$ and methane [1-3]. They are also an integral part of biogas reactors and contribute to the production of the combustible gas methane that is a source of renewable energy $[4,5]$. Methanogenic archaea use end products of anaerobic bacterial degradation processes like $\mathrm{H}_{2} / \mathrm{CO}_{2}$ and acetate as substrates for growth. It is estimated that about two thirds of the methane produced by methanogenic archaea on earth derives from acetate degradation [6]. But despite its high abundance only two genera are able to use acetate as substrate for methanogenesis, namely, Methanosarcina and Methanosaeta. While Methanosarcina species are metabolically versatile, members of the genus Methanosaeta are specialized on acetate utilization. This is reflected in a very high affinity for the substrate. For growth, a minimal concentration of only
$7-70 \mu \mathrm{M}$ is needed [7]. Therefore, Methanosaeta species prevail over members of the genus Methanosarcina in low acetate environments frequently encountered in natural habitats. Important biotechnological habitats are biogas facilities [812], where Methanosaeta species are of special importance for reactor performance and stability $[12,13]$.

In acetate-degrading (aceticlastic) methanogenesis, acetate first has to be activated at the expense of ATP. This reaction can be catalysed by the high activity but low affinity acetate kinase/phosphotransacetylase (AK/PTA) system that is used by Methanosarcina sp. [14, 15] or by the low-activity but high-affinity AMP-dependent acetyl-CoA-synthetases (ACS) [16-18]. While the AK/PTA system generates ADP, $P_{i}$ and acetyl-CoA from ATP, CoA, and acetate $[15,19,20]$, the ACS converts ATP, CoA, and acetate to acetyl-CoA, AMP and pyrophosphate $\left(\mathrm{PP}_{\mathrm{i}}\right)[16,18]$. In the first step of aceticlastic methanogenesis, acetyl-CoA is cleaved into its methyl and carbonyl moiety by the action of a CO dehydrogenase/acetyl$\mathrm{CoA}$ synthase. In the course of this reaction, the carbonyl 
group is oxidized to $\mathrm{CO}_{2}$ and electrons are transferred to ferredoxin [21-23]. The methyl group is donated to the methanogenic cofactor tetrahydrosarcinapterin and subsequently transferred to coenzyme $\mathrm{M}$ (CoM) by a membrane bound $\mathrm{Na}^{+}$translocating methyltransferase. Reduction of the methyl group to methane with coenzyme B as electron donor leads to the formation of the so-called heterodisulfide (CoM-S-S-CoB). Only recently we demonstrated that Methanosaeta (Mt.) thermophila uses the heterodisulfide as terminal electron acceptor in an anaerobic respiratory chain with reduced ferredoxin as the sole electron donor [24]. However, the way this organism conserves energy is not yet fully understood. It can be estimated that the amount of ions translocated over the cytoplasmic membrane in the course of aceticlastic methanogenesis could be sufficient for the phosphorylation of two ADP molecules. Yet AMP-dependent acetyl-CoA synthetase and soluble pyrophosphatase (PPiase) activities could be demonstrated for the closely related $\mathrm{Mt}$. concilii $[16,18,25]$. Taking non-energy coupled hydrolysis of pyrophosphate into account, two ATP equivalents are consumed in the course of the acetate activation reaction. According to this model, the obligate aceticlastic methanogen $\mathrm{Mt}$. thermophila is not able to conserve energy during methanogenesis. To clarify this contradiction, the acetate activation reaction in $M t$. thermophila was reevaluated by gene expression analysis and characterization of ACS and PPiase.

\section{Materials and Methods}

2.1. Materials. All chemicals and reagents were purchased from Sigma-Aldrich (Munich, Germany) or Carl Roth GmbH (Karlsruhe, Germany). Restriction endonucleases, T4 DNA ligase, Taq DNA polymerase, and PCR reagents were purchased from Fermentas (St. Leon-Rot, Germany). Phusion DNA polymerase was purchased from New England Biolabs (Frankfurt am Main, Germany). Oligonucleotides were synthesized by Eurofins (Ebersberg, Germany).

2.2. Bioinformatics. For Blast analyses, the respective tool on NCBI (http://www.ncbi.nlm.nih.gov/) was used. For the batch Blast analysis, those proteins that had a threshold E-value $<\mathrm{e}^{-40}$ were referred to as homologous. The programs PsiPred (http://bioinf.cs.ucl.ac.uk/psipred/) and InterPro (http://www.ebi.ac.uk/interpro/) were utilized for bioinformatic analyses of CBS domains.

2.3. qRT-PCR. Total RNA from Mt. thermophila DSM 6194 was isolated by TRI Reagent extraction. $250 \mathrm{~mL}$ cultures were grown anaerobically to the mid- to late- exponential growth phase in DSMZ medium 387 at $55^{\circ} \mathrm{C}$ with $50 \mathrm{mM}$ sodium acetate. The cultures were filled into centrifuge tubes in an anaerobic hood and were quick-chilled by shaking in an ice-cold ethanol bath $\left(-70^{\circ} \mathrm{C}\right)$ for $5 \mathrm{~min}$. Afterwards, cells were harvested under anaerobic conditions by centrifugation $\left(11000 \times \mathrm{g}, 25 \mathrm{~min}, 4^{\circ} \mathrm{C}\right)$. Cell pellets were resuspended in $5 \mathrm{~mL}$ TRI Reagent and lysed via a freeze-thaw treatment at $-70^{\circ} \mathrm{C}$ overnight. Total RNA was extracted according to the manufacturer's instructions (Ambion, Darmstadt, Germany). Preparations were treated with DNAse I to reduce DNA contaminations. Cleaning and concentration of RNA were achieved using the SurePrep RNA Cleanup and Concentration kit (Fisher Scientific, Schwerte, Germany). RNA purity was quantified spectrophotometrically by examining the $260 \mathrm{~nm} / 280 \mathrm{~nm}$ ratio as well as by denaturing agarose gel electrophoresis.

Primers for qRT-PCR were designed using the Primer3 software (http://frodo.wi.mit.edu/primer3/input.htm). For the highly homologous ACS genes, the least homologous areas were used as templates to guarantee specificity of the primers. The genes encoding glyceraldehyde-3-phosphate dehydrogenase (GAP-DH, mthe_0701) and ribosomal protein S3P (mthe_1722) were chosen as reference genes. Sequences of the primers used can be seen from Table 1.

PCR reactions were performed according to the manufacturer's instructions (http://www1.qiagen.com) with on average $250 \mathrm{ng}$ of RNA. The QuantiTect SYBR Green RT-PCR kit (Qiagen, Hilden, Germany) and the iCycler (Bio-Rad, Munich, Germany) were used for labeling and quantification, respectively. For data analysis, the Bio-Rad iCycler software was used. Each PCR product gave a single narrow peak in the melting curve analysis. A relative value $\left(\Delta \mathrm{C}_{t}\right)$ for the initial target concentration in each reaction was determined by subtracting $\mathrm{C}_{t}$ values of the reference genes from those of the genes of interest. By subtracting $\Delta \mathrm{C}_{t}$ values, comparisons among the genes of interest could be accomplished. In addition, negative-control assays were included that were not incubated with reverse transcriptase. These assays contained only traces of DNA that were not removed by DNase treatment. The $\mathrm{C}_{t}$ values of the negative controls were analyzed and were at least five cycles higher than the assays with reverse transcriptase treatment.

2.4. Cloning into Expression Vectors. Genes from Mt. thermophila were amplified from chromosomal DNA extracted with CTAB [26]. Restriction endonuclease sites were inserted by PCR; Primers had the following sequences (recognition sites for restriction endonucleases are underlined): mthe_0236 for ATGGTAGGTCTCAAATGGCAGATAATATCTATGTGGTCGGG, mthe_0236 rev ATGGTAGGTCTCAGCGCTCTTCTTGAATGCGGACTCGAGC, mthe_1194 for ATGGTAACCTGCATTAGCGCCGCTGAGACTGCAAAGACTGCTG, $m$ the $1194 \mathrm{rev}$ ATGGTAACCTGCATTATATCAGACTATGAGCGGGATGTTCTCG. For cloning of the pyrophosphatase gene (mthe_0236), Eco31I was used, for cloning of the AMPdependent ACS gene (mthe_1194) BveI. Amplicons were cut and ligated into pASK-IBA3 or pASK-IBA5 (IBA GmbH, Göttingen, Germany) to produce pASK-mthe0236-3 and pASK-mthe1194-5, respectively. Both vectors contained plasmid encoded ribosomal binding sites and a Strep-tag II either C-terminal (pASK-IBA3) or N-terminal (pASKIBA5). The constructs were confirmed by sequencing and transformed into E. coli [27].

2.5. Protein Overproduction and Purification. Overproduction of proteins was performed in E. coli BL21 (DE3) 
TABLE 1: Gene number, function of corresponding protein and primers used for amplification of genes analyzed by qRT-PCR.

\begin{tabular}{|c|c|c|}
\hline Function & Gene number & Primer sequence \\
\hline \multirow{8}{*}{ AMP-dependent ACS } & \multirow{2}{*}{ mthe_1194 } & for CCAGTGGATCATCGAGTA \\
\hline & & rev CAGAAATCGAGGTAGTTC \\
\hline & \multirow{2}{*}{ mthe_1195 } & for TAAGGAGCTTGCTGAGAA \\
\hline & & rev CAGAACTCTATGTAGTGG \\
\hline & \multirow{2}{*}{ mthe_1196 } & for TCGAAGGCGTATGCTGAC \\
\hline & & rev CGCCTCGTCAGCCTGCTT \\
\hline & \multirow{2}{*}{ mthe_1413 } & for CAGGCGCGCTCCGCGAG \\
\hline & & rev GGCCTTTATCGGGATAGG \\
\hline \multirow{2}{*}{ ADP-dependent ACS } & \multirow{2}{*}{ mthe_0554 } & for TATCATTGGGGTTACAAG \\
\hline & & rev CAGAGATGGGTATTGATC \\
\hline \multirow{2}{*}{ PPiase } & \multirow{2}{*}{ mthe_0236 } & for GCCAGCATGTATGAGCTG \\
\hline & & rev CATGTGGGTGACTTGAAT \\
\hline \multirow{2}{*}{ GAP-DH } & \multirow{2}{*}{ mthe_0701 } & for CTATGCCGTTGCTGTGAA \\
\hline & & rev TTGGCGGTGCATTTATCT \\
\hline \multirow{2}{*}{ ribosomal protein $\mathrm{S} 3 \mathrm{P}$} & \multirow{2}{*}{ mthe_1722 } & for GTTCGTCATGATTGGCAC \\
\hline & & rev CCCCTTCTGGAGCTTATC \\
\hline \multirow{2}{*}{ intergenic region } & Between mthe_1194 & for GCGGTCAACCTATTTTATTT \\
\hline & and mthe_1195 & rev TTACATACСТCСАТТСАТСТ \\
\hline \multirow{2}{*}{ intergenic region } & Between mthe_1195 & for AACGTCCGCAATTTTTATTT \\
\hline & and mthe_1196 & rev CTGCCTCCAGCCCATCCCG \\
\hline
\end{tabular}

including the plasmid pLysS (Novagen/Merck, Darmstadt, Germany). Cells were grown on modified maximal induction medium [28] with $3.2 \%[\mathrm{w} / \mathrm{v}]$ tryptone, $2 \%[\mathrm{w} / \mathrm{v}]$ yeast extract, and additions of $\mathrm{M} 9$ salts as well as $0.1 \mathrm{mM} \mathrm{CaCl}_{2}$, $1 \mathrm{mM} \mathrm{MgSO}_{4}$ and $1 \mu \mathrm{M}$ ammonium iron(III) citrate. Ampicillin $\left(100 \mu \mathrm{g} \mathrm{mL}^{-1}\right)$ and chloramphenicol $\left(25 \mu \mathrm{g} \mathrm{mL}^{-1}\right)$ were added for plasmid maintenance. Cultures were grown aerobically at $37^{\circ} \mathrm{C}$ to an $\mathrm{OD}_{600}$ of 0.6 ; protein production was induced by addition of anhydrotetracyclin $\left(200 \mathrm{ng} \mathrm{mL}^{-1}\right)$. Cells were allowed to grow for another 3-4 hours, harvested by centrifugation $(11000 \times \mathrm{g}, 10 \mathrm{~min})$ and lysed by sonication. Protein purification by Strep-tactin affinity chromatography was performed aerobically according to the manufacturer's instructions (IBA GmbH, Göttingen, Germany). The purified protein was stored at $-70^{\circ} \mathrm{C}$.

2.6. Protein Visualisation. SDS-PAGE was done according to Laemmli [29] with a $5 \%[\mathrm{w} / \mathrm{v}]$ polyacrylamide stacking gel and a $12.5 \%[\mathrm{w} / \mathrm{v}]$ slab gel. Samples were diluted in sample loading buffer $(2 \%[\mathrm{w} / \mathrm{v}]$ SDS, $5 \%[\mathrm{v} / \mathrm{v}] \beta$-mercaptoethanol, $50 \%[\mathrm{v} / \mathrm{v}$ ] glycerol, $20 \%[\mathrm{v} / \mathrm{v}]$ collecting buffer $(0.625 \mathrm{M}$ Tris$\mathrm{HCl} \mathrm{pH} 6.8), 0.001 \%[\mathrm{w} / \mathrm{v}]$ bromophenol blue), boiled for $5 \mathrm{~min}$ at $95^{\circ} \mathrm{C}$ and loaded to the gel. Molecular masses were calculated by comparison to a molecular mass standard (Fermentas, St. Leon-Rot, Germany). Proteins were visualized by silver staining [30].

2.7. Gel Filtration Chromatography. For gel filtration chromatography a Hi Load 16/60 Superdex 75 prep grade column (GE Healthcare, Munich, Germany) was employed. Calibration was done using the kit for molecular weights,
29000-700000 for gel filtration chromatography (SigmaAldrich, Munich, Germany) according to the manufacturer's instructions. For determination of the void volume Blue Dextran was employed. The $K_{\mathrm{av}}$ was calculated according to

$$
K_{\mathrm{av}}=\frac{\left(v_{e}-v_{o}\right)}{\left(v_{c}-v_{o}\right)},
$$

$v_{e}$ being the elution volume, $v_{o}$ the void volume and $v_{c}$ the column volumn. $K_{\mathrm{av}}$ was plotted against the decadal logarithm of the molecular weight of the proteins used for calibration, and the resulting curve was used for molecular mass determination. Averaged $1.5 \mathrm{mg}$ of the soluble pyrophosphatase were loaded and run in $40 \mathrm{mM}$ Tris- $\mathrm{HCl}$ $\mathrm{pH} 8,150 \mathrm{mM} \mathrm{NaCl}$, and $1 \mathrm{mM} \mathrm{MnCl} 2$ at a rate of $0.5 \mathrm{~mL}$ $\min ^{-1}$.

2.8. Enzyme Assays. Assay mixtures for Mthe_0236 routinely contained $200 \mu \mathrm{L}$ total volume with $40 \mathrm{mM}$ Tris- $\mathrm{HCl} \mathrm{pH}$ $8,5 \mathrm{mM} \mathrm{MgCl} 2$ and $1 \mathrm{mM} \mathrm{PP}$. For measuring the manganese containing enzyme, the protein preparation was preincubated for $5 \mathrm{~min}$ at room temperature in $40 \mathrm{mM}$ Tris$\mathrm{HCl} \mathrm{pH} 8,5 \mathrm{mM} \mathrm{MgCl}_{2}$ and $1 \mathrm{mM} \mathrm{MnCl}_{2}$ prior to the measurement. For measuring inhibitory effects of nucleotides, either $750 \mu \mathrm{M}$ AMP or $5 \mu \mathrm{M}$ ADP were included. For measuring the effect of phosphate between 0 and $1.5 \mathrm{mM}$, $\mathrm{KH}_{2} \mathrm{PO}_{4}$ were added. The activity of the pyrophosphatase was determined with a discontinuous assay so samples were taken at different time points and the content of the reaction product orthophosphate was measured (modified after Saheki et al. [31]). Values were compared to standard curves $\left(0-2 \mathrm{mM} \mathrm{P}_{\mathrm{i}}\right)$. To run more reactions in parallel, tests were performed in 96 -well plates. Therefore, $10 \mu \mathrm{L}$ of sample 
from the assay mixture were stopped with $2 \mu \mathrm{L} 10 \%[\mathrm{w} / \mathrm{v}]$ trichloroacetic acid. $150 \mu \mathrm{L}$ of molybdate reagent $(15 \mathrm{mM}$ $\left(\mathrm{NH}_{4}\right)_{6} \mathrm{Mo}_{7} \mathrm{O}_{24}, 70 \mathrm{mM}$ zinc acetate, $\mathrm{pH} 5.0$ with $\left.\mathrm{HCl}\right)$ were added as well as $50 \mu \mathrm{L}$ of $10 \%[\mathrm{w} / \mathrm{v}]$ ascorbic acid (pH 5.0 with $\mathrm{NaOH}$ ). After incubation at $30^{\circ} \mathrm{C}$ for $15 \mathrm{~min}$, absorption at $850 \mathrm{~nm}$ was measured with the Nanoquant Infinite M200 (Tecan, Männedorf, Switzerland). One unit was defined as $\mu \mathrm{mol} \mathrm{PP}_{\mathrm{i}}$ hydrolyzed $\mathrm{min}^{-1}$.

For measuring the activity of the AMP-dependent ACS (Mthe_1194) two different methods were employed. Temperature stability, the $\mathrm{K}_{M}$ value for acetate, and inhibition by $\mathrm{PP}_{\mathrm{i}}$ were measured via auxiliary enzymes according to a method modified after Meng et al. [32] (Table 2). In this method production of AMP by Mthe_1194 was coupled to NADH consumption that was followed photometrically at $340 \mathrm{~nm}$. In a standard $1 \mathrm{~mL}$ assay $50 \mathrm{mM}$ HEPES $\mathrm{pH}$ 7.5, $5 \mathrm{mM} \mathrm{MgCl}_{2}, 3 \mathrm{mM}$ phosphoenolpyruvate, $1 \mathrm{mM} \mathrm{CoA}$, $2.5 \mathrm{mM}$ ATP, $1 \mathrm{mM}$ DTT, $20 \mathrm{mM}$ sodium acetate, and $0.15 \mathrm{mM}$ NADH were included. Reaction temperature was set to $55^{\circ} \mathrm{C}$. Auxiliary enzymes were sufficiently stable at this temperature, and the amounts of auxiliary enzymes $(5.7 \mathrm{U}$ myokinase, $2.3 \mathrm{U}$ pyruvate kinase, $2.1 \mathrm{U}$ lactate dehydrogenase) were not rate limiting. The extinction coefficient of $\mathrm{NADH}$ was $6.22 \mathrm{mM}^{-1} \mathrm{~cm}^{-1}$. One unit was defined as one $\mu \mathrm{mol}$ of acetate consumed per min that was equal to two $\mu$ mols of NADH consumed per min.

The $\mathrm{K}_{M}$ values for ATP and CoA (reaction volume $3.5 \mathrm{~mL}$ ) as well as substrate specificity (reaction volume $2 \mathrm{~mL}$ ) were determined by using a discontinuous assay. At different time points $380 \mu \mathrm{L}$ samples were taken and the content of $\mathrm{PP}_{\mathrm{i}}$ was measured according to a method modified after Kuang et al. [33]. The reaction in the samples was stopped with $380 \mu \mathrm{L} 12 \%$ TCA [w/v] and $100 \mu \mathrm{L}$ molybdate reagent $\left(2.5 \%[\mathrm{w} / \mathrm{v}]\left(\mathrm{NH}_{4}\right)_{6} \mathrm{Mo}_{7} \mathrm{O}_{24}\right.$ in $\left.5 \mathrm{~N} \mathrm{H}_{2} \mathrm{SO}_{4}\right), 100 \mu \mathrm{L}$ $0.5 \mathrm{M} \beta$-mercaptoethanol and $40 \mu \mathrm{L}$ Eikonogen reagent were added for detection of $\mathrm{PP}_{\mathrm{i}}$. The Eikonogen reagent was prepared by dissolving $0.25 \mathrm{~g} \mathrm{Na}_{2} \mathrm{SO}_{3}, 14.65 \mathrm{~g} \mathrm{KHSO}_{3}$ and

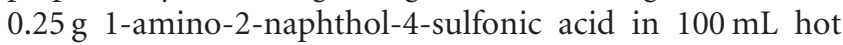
water. The solution was cooled down and filtered before use. The reaction mixture for $\mathrm{PP}_{\mathrm{i}}$ analysis was incubated for $15 \mathrm{~min}$ at $37^{\circ} \mathrm{C}$ and the absorption at $580 \mathrm{~nm}$ measured. Quantification was done using standard curves $(0-0.5 \mathrm{mM}$ $\mathrm{PP}_{\mathrm{i}}$ ). One unit was defined as $\mu \mathrm{mol}$ acetate depleted per min.

\section{Results}

3.1. Comparison of Genomes of Methanosaeta thermophila and Methanosarcina mazei. The recently completed genome sequence of $M t$. thermophila [23] indicated that the majority of the core steps of aceticlastic methanogenesis are similar in comparison to the genus Methanosarcina, but striking differences have been discovered in electron transfer reactions and energy conservation apparatus. These findings led us to a detailed and comprehensive comparison of proteins. A batch Blast analysis of all amino acid sequences from $\mathrm{Ms}$. mazei against $M t$. thermophila and vice versa was performed. In summary, there were about 900 proteins identified that were present in Ms. mazei and Mt. thermophila (not shown). Among the homologs are enzymes that participate in the
TABLE 2: Activity measurement of the acetyl-CoA synthetase via auxiliary enzymes. The decrease of the absorption of NADH was tracked photometrically at $340 \mathrm{~nm}$.

\begin{tabular}{lc}
\hline Enzyme & Reaction catalyzed \\
\hline Acetyl-CoA synthetase & acetate $+\mathrm{ATP}+\mathrm{CoA} \rightleftharpoons$ acetyl-CoA \\
Myokinase & $+\mathrm{PP}_{\mathrm{i}}+\mathrm{AMP}$ \\
Pyruvate kinase & $\mathrm{AMP}+\mathrm{ATP} \rightleftharpoons 2 \mathrm{ADP}$ \\
Lactate dehydrogenase & $\mathrm{ADP}+\mathrm{PEP} \rightleftharpoons$ pyruvate $+\mathrm{ATP}$ \\
& pyruvate $+\mathrm{NADH} \rightleftharpoons$ lactate + \\
\end{tabular}

central part of aceticlastic methanogenesis and proteins involved in DNA replication, transcription, and translation. Taking into account that the genome of Mt. thermophila codes for 1698 proteins, about 800 proteins found in Mt. thermophila had no counterpart in Ms. mazei. On the other hand, Ms. mazei contains 3371 genes indicating that about 2500 proteins can be produced in Ms. mazei that are not found in Mt. thermophila.

A detailed inspection of the genome of Mt. thermophila revealed that the respiratory chain is simpler in comparison to Methanosarcina species and is composed only of the $\mathrm{F}_{420} \mathrm{H}_{2}$ dehydrogenase and the heterodisulfide reductase. There are no genes on the chromosome that encode hydrogenases (neither $\mathrm{F}_{420}$-reducing hydrogenase (Frh) and $\mathrm{F}_{420}$-nonreducing hydrogenase (Vho), nor Ech hydrogenase) [23] or the Rnf complex (encoding a membrane-bound enzyme able to oxidize reduced ferredoxin) [23]. Also membrane fractions of $M t$. thermophila were shown not to exhibit any hydrogenase activity [24]. In addition, there is no membrane-bound pyrophosphatase and the electron input module of the $\mathrm{F}_{420} \mathrm{H}_{2}$ dehydrogenase FpoF [34] is also missing. Furthermore, genes for acetate kinase and phosphotransacetylase are absent. In contrast to this limited equipment, $\mathrm{Mt}$. thermophila possesses four genes encoding acetyl-CoA synthetases (ACS) [23]. No homologs to these four genes are found in Methanosarcina species. There was no evidence for a membrane-bound pyrophosphatase that could couple the hydrolysis of pyrophosphate to ion extrusion [35] and thus contribute to energy conservation. Instead, a single soluble type II pyrophosphatase was identified (mthe_0236) [23].

3.2. Characterization of the Pyrophosphatase. The current hypothesis of the acetate activating reaction in Methanosaeta species is that pyrophosphate, produced in the course of acetyl-CoA formation, is hydrolyzed by a pyrophosphatase [25]. However, from our knowledge of the energy conserving system of these organisms it is evident that at least part the energy from the pyrophosphate bond has to be conserved. Therefore, the soluble pyrophosphatase from $M t$. thermophila was characterized with respect to gene expression and enzyme activity.

The transcript level of the gene encoding the soluble type II pyrophosphatase was analyzed by qRT-PCR experiments. The number of transcripts was three- to four fold higher than that of the reference genes encoding GAP-DH and 


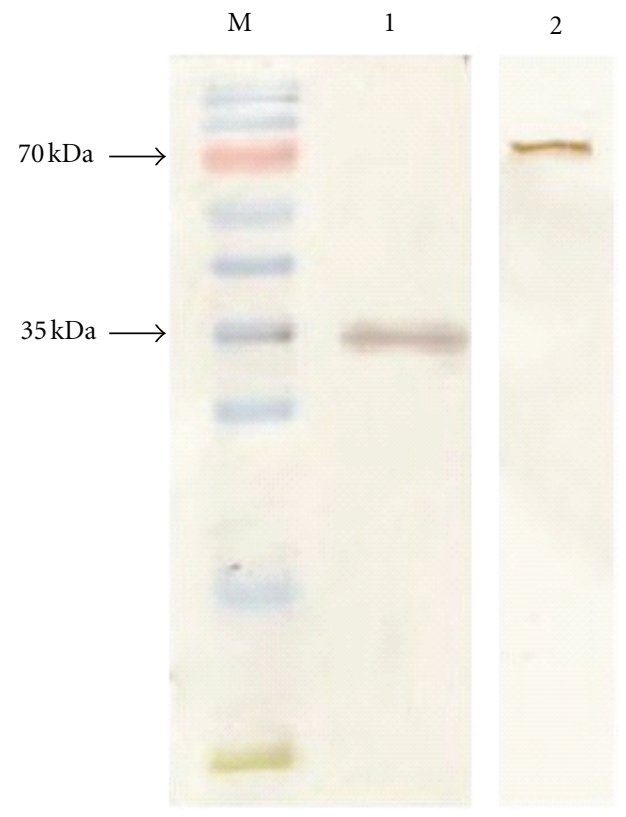

Figure 1: SDS-PAGE analysis of purified soluble pyrophosphatase (Mthe_0236) and AMP-dependent ACS (Mthe_1194). Enzymes were purified by Strep-tactin affinity chromatography. M: molecular mass marker (PAGE Ruler prestained protein ladder, Fermentas, St. Leon-Rot, Germany), lane 1: Mthe_0236 $0.5 \mu g$, lane 2: Mthe_1194 $1 \mu \mathrm{g}$.

ribosomal protein S3P (Figure S1). Since at least the gene encoding the S3P protein has to expressed in high amounts for efficient ribosome formation, it is evident that the soluble pyrophosphatase mRNA exists in great copy numbers in cells of Mt. thermophila.

Furthermore, the soluble type II pyrophosphatase was found to contain a single CBS domain situated near the $\mathrm{N}$-terminus that could have regulatory effects triggered by binding of ligands such as AMP and ADP [36-38]. Consequently, the pyrophosphatase from $\mathrm{Mt}$. thermophila could be potentially inhibited under low-energy conditions (low ATP/ADP ratio) enabling the cell to take advantage of the phosphate group transfer potential of pyrophosphate.

Blast analyses revealed that CBS domains are rarely found in pyrophosphatases of methanogenic archaea. They could only be identified in soluble pyrophosphatases from species of Methanosaeta, Methanocaldococcus, and Methanotorris. However, biochemical data exists only for the pyrophosphatase from Mt. concilii [25]. Thus, functionality of CBS domains in pyrophosphatases of methanogenic archaea has not yet been shown. To evaluate the kinetic parameters of the pyrophosphatase from Mt. thermophila, the gene mthe_0236 was cloned into an expression vector and the respective protein was overproduced in E. coli. A single band was detected at $35 \mathrm{kDa}$ on the SDS gel after Streptactin affinity purification (Figure 1). This was in accordance with the predicted molecular mass of $35 \mathrm{kDa}$. The native conformation of the pyrophosphatase was assayed by gel

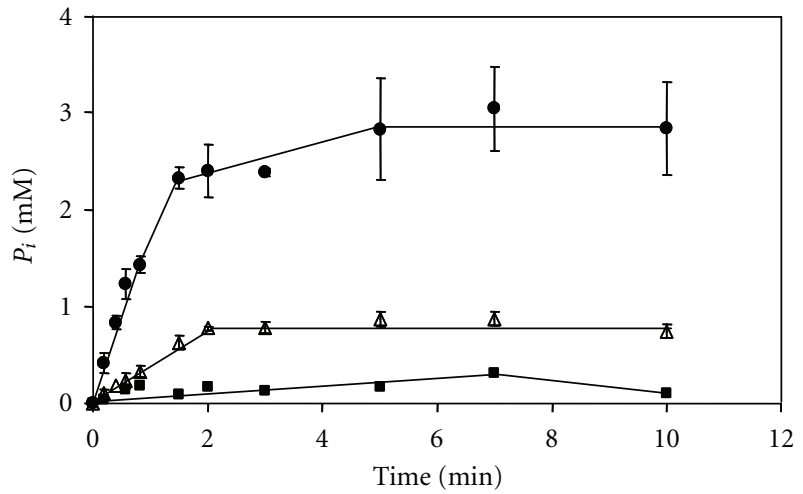

FIgure 2: Activity measurement of the soluble type II pyrophosphatase (Mthe_0236). Assays contained $40 \mathrm{mM}$ Tris-HCl pH 8 with $5 \mathrm{mM} \mathrm{MgCl}{ }_{2}$ and $1.25 \mu \mathrm{g}$ enzyme/mL. $(\bullet)$ activity measurement after $5 \mathrm{~min}$ preincubation with $1 \mathrm{mM} \mathrm{MnCl}_{2},(\Delta)$ activity without preincubation, and (ם) control without Mthe_0236.

filtration chromatography. The molecular mass of the native enzyme was $71.4 \pm 5 \mathrm{kDa}$. Thus, the native pyrophosphatase was a homodimer. Crystal structures of the soluble type II pyrophosphatases from Bacillus subtilis, Streptococcus gordonii, and Streptococcus mutans revealed that these enzymes are also homodimers in their native conformation $[39,40]$.

Kinetic analysis showed that the $\mathrm{v}_{\max }$ of the enzyme was $157 \pm 33 \mathrm{U} / \mathrm{mg}$ with $\mathrm{Mg}^{2+}$ and $726 \pm 40 \mathrm{U} / \mathrm{mg}$ with $\mathrm{Mn}^{2+}$ as metal cofactor (Figure 2). The $\mathrm{K}_{\mathrm{M}}$-value for $\mathrm{PP}_{\mathrm{i}}$ was measured with $\mathrm{Mn}^{2+}$ as metal ion in the catalytic center and was found to be $0.27 \pm 0.05 \mathrm{mM}$. As indicated earlier, the presence of the CBS domain pair pointed towards a possible regulation of enzyme activity by nucleotides. However, our experiments demonstrated that the pyrophosphatase was not inhibited by nucleotides or its end product phosphate: neither addition of $750 \mu \mathrm{M}$ AMP or $5 \mu \mathrm{M}$ ADP nor addition of up to $1.5 \mathrm{mM}$ phosphate led to a reduced reaction rate. Hence, the results indicate that the single CBS domain found in the soluble pyrophosphatase of $\mathrm{Mt}$. thermophila is not involved in the regulation of enzyme activity. In contrast, two CBS domains (referred to as Bateman domain [38]) were identified in the membrane-bound pyrophosphatase from the bacterium Moorella thermoacetica and inhibition by adenine nucleotides was demonstrated [41].

3.3. Characterization of the ACS. The genome of Mt. thermophila contains four genes encoding putative AMPdependent ACS enzymes, three of which are tandemly positioned (mthe_1194-mthe_1196). The gene encoding the fourth putative ACS is located elsewhere as a single gene (mthe_1413). Additionally, we identified a gene encoding a putative ADP-dependent acetyl-CoA-synthetase (mthe_0554).

To unravel which of the ACS enzymes catalyzes the acetate activation reaction in vivo, the transcript amount of the respective genes was investigated. qRT-PCR experiments demonstrated that mthe_1194 is the most abundantly expressed of the ACS genes (see Figure S1 in Supplementary 
Material available online at doi: 10.1155/2012/315153). The transcript level of mthe_1194 was 2.6 and 2.0 fold higher in comparison to the gap gene and the gene encoding the S3P protein, respectively. In contrast, the other ACS encoding genes $m$ the_1195 and mthe_1196 showed 23-fold and 37-fold reduced transcript concentrations compared to mthe1194, respectively. Expression of the single gene mthe_1413 was only slightly lower than expression of $m$ the_1194, whereas the mRNA content of the putative ADP-dependent acetyl-CoAsynthetase, $m$ the_0554, was about 4000-fold lower under the chosen growth conditions and was near to the detection limit of our assays.

The question arose whether the ACS encoding genes mthe_1194-1196 are organized in one operon. A closer inspection indicated that the genes are separated by at least $300 \mathrm{bp}$ that contain potential transcriptional starting elements (TATA and BRE boxes). Therefore, the organization of this gene cluster was further analyzed by qRT-PCR using primers pairs that bridged the intergenic regions starting from the beginning and the end of the acs genes. With this technique, we could detect mRNA that covered the intergenic regions between the genes. The results of qRT-PCR clearly indicated that the intergenic region between mthe_1195 and mthe_1196 was transcribed to the same extent as the genes themselves, indicating that mthe_1195 and mthe_1196 were transcribed together (see Figure S1). For the intergenic region between $m$ the 1194 and $m$ the_1195 no transcript could be detected. Hence, it is highly possible that mthe_1194 represented a single transcriptional unit.

As the ACS encoded by mthe_1194 was found to be the most abundantly expressed acetate activation enzyme, it was overexpressed in E. coli and the corresponding protein was purified via Strep-tactin affinity chromatography. SDS-PAGE and silver staining revealed a single band at approximately $75 \mathrm{kDa}$, which was in accordance with the predicted molecular mass (Figure 1).

Enzymatic measurements revealed that Mthe_1194 is a thermostable enzyme since $85 \%$ of the original activity was retained after incubation at $55^{\circ} \mathrm{C}$ for $30 \mathrm{~min}$ (Figure 3 ). The optimal growth temperature of $\mathrm{Mt}$. thermophila is $55^{\circ} \mathrm{C}$ and was thus chosen as standard temperature for all enzymatic measurements. In an assay that coupled the formation of AMP to the oxidation of NADH via auxiliary enzymes (see Section 2) a maximal activity of $21.7 \mathrm{U} / \mathrm{mg}$ was measured with a $\mathrm{K}_{M}$ value for acetate at $0.4 \mathrm{mM}$. An alternate assay utilizing the detection of the pyrophosphate resulted in a maximal activity of $28 \mathrm{U} / \mathrm{mg}$. This test was also used to determine $\mathrm{K}_{M}$ values for ATP and CoA, which were found to be $20 \mu \mathrm{M}$ and $14.5 \mu \mathrm{M}$, respectively. To differentiate whether the ACS Mthe_1194 was involved only in the activation of acetate in energy metabolism or also in the metabolism of fatty acids, the substrate spectrum was tested. As expected from an enzyme involved in energy metabolism, the enzyme specifically converted acetate to the corresponding thioester. A reaction was also observed with propionate but the specific activity was only $1 \%$ compared to the reactivity with acetate. Butyrate did not serve as a substrate for the ACS. It was observed that AMP, ADP, ATP or $\mathrm{P}_{\mathrm{i}}$ did not inhibit Mthe_1194. In contrast, addition of the final product $\mathrm{PP}_{\mathrm{i}}$

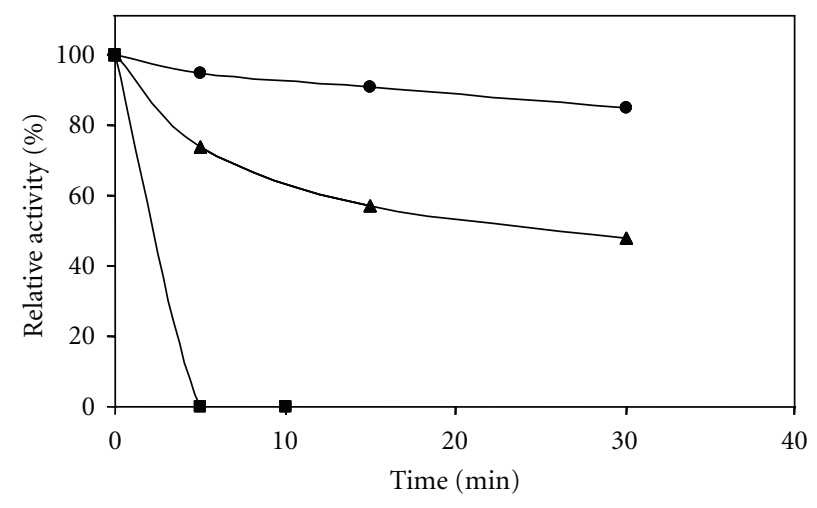

FIgURE 3: Temperature stability of the AMP-dependent ACS Mthe_1194. (•) Incubation at $55^{\circ} \mathrm{C},(\boldsymbol{\Delta})$ incubation at $75^{\circ} \mathrm{C}$, and (ם) incubation at $92^{\circ} \mathrm{C}$. Enzyme activity was measured in the $\mathrm{NADH}$ consumption assay with auxiliary enzymes at $55^{\circ} \mathrm{C}$.

led to inhibition of enzyme activity. Addition of $0.25 \mathrm{mM}$ pyrophosphate resulted in $50 \%$ reduction of the reaction rate.

A central question of the acetate activation reaction in $M t$. thermophila is whether the energy that is released by the hydrolysis of ATP to AMP and pyrophosphate (2) is sufficient to drive the activation reaction or whether it is necessary to additionally hydrolyse the pyrophosphate to two inorganic phosphates (3) [42]:

$$
\begin{array}{rr}
\mathrm{ATP} & \longrightarrow \mathrm{AMP}+\mathrm{PP}_{\mathrm{i}} \quad \Delta G_{0}^{\prime}=-31 \mathrm{~kJ} / \mathrm{mol}[42] \\
\mathrm{PP}_{\mathrm{i}} \longrightarrow 2 \mathrm{P}_{\mathrm{i}} & \Delta G_{0}^{\prime}=-20 \mathrm{~kJ} / \mathrm{mol}[42]
\end{array}
$$

Therefore, the activation energy of acetyl-CoA formation by Mthe_1194 was determined. For this purpose, the reaction rate between 20 and $92^{\circ} \mathrm{C}$ was measured and the natural logarithm of the specific activity plotted against the reciprocal value of the absolute temperature. The activation energy was calculated by using (4) and was $30 \mathrm{~kJ} / \mathrm{mol}$.

$$
E_{a}=-m \cdot R,
$$

where $R$ is the universal gas constant and $m$ is the slope $(R=$ $\left.8.314 \mathrm{~J} \mathrm{~mol}^{-1} \mathrm{~K}^{-1}, m=-3535,5 \mathrm{~K}^{-1}\right)$.

\section{Discussion}

Methanogenic archaea performing aceticlastic methanogenesis are living at the thermodynamic limit as the free energy change of this reaction is only $-36 \mathrm{~kJ} / \mathrm{mol}$. The first step of acetate breakdown is acetate activation. It was proposed that this step differs in the two genera that are able to grow on acetate, Methanosarcina and Methanosaeta. For Methanosarcina sp., it is well established that the acetate kinase/phosphotransacetylase system is used for acetate activation $[43,44]$. It is of bacterial origin and was acquired by Methanosarcina sp. by lateral gene transfer [45]. In this pathway acetate is activated to acetyl phosphate with concomitant hydrolysis of ATP to ADP and phosphate. In the subsequent step, acetyl phosphate is transformed into 
acetyl-CoA without further expense of ATP. In total, one ATP equivalent is hydrolyzed. For Methanosaeta sp., however, the acetate activation reaction is more ambiguous. The genome sequences of Mt. concilii and Mt. thermophila indicate that the acetate kinase/phosphotransacetylase enzyme system is absent in these organisms $[23,46]$. In addition, these enzyme activities could not be found in cell extract of Mt. concilii [17]. Instead, it was proposed that an AMP-dependent acetyl-CoA synthetase should catalyze this reaction [18]. Jetten et al. purified one of these enzymes from $M t$. concilii $[18]$ that converts acetate to acetyl-CoA and thereby hydrolyzes ATP to AMP and $\mathrm{PP}_{\mathrm{i}}$. Together with the activity of a soluble pyrophosphatase that was purified by the same group [25] this mode of activation requires the hydrolysis of two ATP equivalents. However, the anaerobic respiratory chain of Methanosaeta sp. is purported to be incapable of supporting the generation of more than two ATP molecules from one acetate molecule [24]. Hence, it is rather intriguing how these organisms generate metabolic energy for growth. To overcome this contradiction, we reevaluated the acetate activation reaction in $M t$. thermophila.

In the genome of Mt. thermophila, five different putative ACS enzymes are encoded, four are annotated as AMP-dependent and one as ADP-dependent. So far ADPdependent acetyl-CoA-synthetases have never been shown to work in the direction of acetyl-CoA formation in vivo. Nevertheless, this possibility was considered due to its energetic benefit to the cell. However, qRT-PCR experiments clearly demonstrated that the respective gene is not expressed during the exponential growth phase. Therefore, and because the acetate kinase/phosphotransacetylase system is missing, acetate activation in Mt. thermophila is probably catalyzed by an AMP-dependent ACS. It could be shown that one of the four genes encoding AMP-dependent ACS, mthe_1194, was the most abundantly expressed. Therefore, the corresponding protein was overproduced and characterized. Involvement in energy metabolism was verified by the fact that acetate is by far the best substrate, which could also be demonstrated for the ACS enzyme from Methanothermobacter thermoautotrophicus [47]. Also the $\mathrm{K}_{M}$ value for ATP was low, which means that acetate activation by Mthe_1194 is possible even under low-energy conditions. Inhibition by AMP has been shown but did not occur in this case $[18,48]$. Instead $\mathrm{PP}_{\mathrm{i}}$ that is the other reaction product and has also been shown to inhibit ACS enzymes $[18,48]$ could reduce the reaction rate by $50 \%$ at a concentration of $0.25 \mathrm{mM}$. Thus, accumulation of excess acetyl-CoA along with ATP consumption is avoided in the cytoplasm of Mt. thermophila.

The close relative Mt. concilii contains five genes encoding putative AMP-dependent ACS enzymes [46]. An ACS from $M t$. concilii was previously purified from cell extracts and characterized and showed similar enzyme properties to the ACS characterized in this study [18]. However, in light of the recent genome sequencing, it is not certain which of the five ACS isozymes was purified from Mt. concilii, or if a mixture of the five highly homologous enzymes $(\geq 58 \%$ identity) was obtained.

The finding that $\mathrm{PP}_{\mathrm{i}}$ is generated during the acetate activation reaction led to the question if the energy released during hydrolysis of $\mathrm{PP}_{\mathrm{i}}$ is dissipated as heat or if it is (at least in part) used for energy conservation. As indicated above, the genome of $M t$. thermophila contains only one pyrophosphatase gene, coding for a soluble type II pyrophosphatase (Mthe_0236). We heterologously overproduced the enzyme in E. coli and the biochemical characterization indicated that the enzyme indeed possessed the characteristics of a soluble type II pyrophosphatase.

The result of gel filtration chromatography showed that the pyrophosphatase from Mt. thermophila is active as a homodimer. In contrast, the pyrophosphatase purified from Mt. concilii was found to be a heterotetramer by gel filtration chromatography and SDS-PAGE analysis [25]. However, there is only one gene encoding a soluble type II pyrophosphatase in the genome of $M t$. concilii [46] that appears as a single transcription unit and is not part of an operon structure. It is tempting to speculate that in Mt. concilii a posttranslational modification takes place and two forms of the protein are produced or the smaller protein is a result of a proteolytic cleavage as a first stage of degradation in a normal turn-over process. A native conformation with three to four subunits was found for the type II soluble pyrophosphatase from Methanocaldococcus jannaschii [49]. In contrast, soluble type II pyrophosphatase purified from bacteria are made of a single subunits and form homodimers $[39,40]$. Hence, the pyrophosphatase from $M t$. thermophila resembles bacterial enzymes with respect to subunit composition.

Pyrophosphate is formed in enzymatic reactions of various metabolic pathways (e.g., DNA, RNA, and protein biosynthesis) and is supposed to be subsequently hydrolyzed by pyrophosphatases to shift the overall reaction equilibrium towards product formation. However, this view may be too restrictive because a considerable amount of metabolic energy is lost and released as heat. Instead, it might be possible that some of the energy of the $\mathrm{PP}_{\mathrm{i}}$ anhydride bond could be conserved. For example, by coupling the hydrolysis of $\mathrm{PP}_{\mathrm{i}}$ to the phosphorylation of cellular compounds thereby forming energy-rich intermediates for biosynthesis. Such enzymes have already been detected in many organisms, such as $\mathrm{PP}_{\mathrm{i}}$-dependent phosphofructokinases from the sulphur-reducing archaeon Thermoproteus tenax [50], bacteria like Methylococcus capsulatus [51], Methylomicrobium alcaliphilum [52], Borrelia burgdorferi [53], and the protozoan Entamoeba histolytica [54]. Another prominent example is the pyruvate phosphate dikinase, catalyzing the reversible reaction between pyruvate, ATP and phosphate to phosphoenolpyruvate, AMP, and pyrophosphate. Among others it has been found in T. tenax [55], Bacteroides symbiosis [56], and Microbispora rosea [57]. Genes encoding $\mathrm{PP}_{\mathrm{i}}$-dependent kinases were not yet annotated in the genome of Mt. thermophila. However, the deduced amino acid sequence from gene $m$ the_1637 revealed a low but significant homology (e-value of $2 \times \mathrm{e}^{-40}$ ) to the pyruvate phosphate dikinase from T. tenax.

The question whether $\mathrm{PP}_{\mathrm{i}}$ is completely hydrolyzed by the pyrophosphatase in Mt. thermophila or whether part of the energy-rich molecule is used for phosphorylation reactions is not clear and will be examined in the future. 
However, the kinetic parameters of the pyrophosphatase from $M t$. thermophila are intriguing. The $\mathrm{K}_{M}$ values for $\mathrm{PP}_{\mathrm{i}}$ of the above-mentioned pyrophosphate-scavenging enzymes generally range between 0.2 and $0.015 \mathrm{mM}$ and are thus below the $\mathrm{K}_{M}$ of $0.3 \mathrm{mM}$ of the pyrophosphatase described here. That means that these could take advantage of part of the pyrophosphate that is released during the process of aceticlastic methanogenesis and thus contribute to the generation of high group transfer potential intermediates that would subsequently contribute to energy conservation.

In summary, it could be shown that the acetate activation reaction in $\mathrm{Mt}$. thermophila requires two ATP equivalents per molecule of acetate. It cannot be excluded that part of $\mathrm{PP}_{\mathrm{i}}$ generated in this process might be used by an unknown enzyme to transfer phosphate groups to an intermediary metabolite. Further investigation into the energy conservation mechanisms of Methanosaeta sp. is needed to understand how these organisms that live close to the thermodynamic limits of life can thrive.

\section{Acknowledgments}

The authors thank Elisabeth Schwab for technical assistance and Paul Schweiger for critical reading of the manuscript. This work was supported by the Deutsche Forschungsgemeinschaft (DE488/10-1).

\section{References}

[1] M. A. K. Khalil and R. A. Rasmussen, "Global emissions of methane during the last several centuries," Chemosphere, vol. 29, no. 5, pp. 833-842, 1994.

[2] R. Conrad and M. Klose, "Anaerobic conversion of carbon dioxide to methane, acetate and propionate on washed rice roots," FEMS Microbiology Ecology, vol. 30, no. 2, pp. 147-155, 1999.

[3] D. S. Reay, "Sinking methane," Biologist, vol. 50, no. 1, pp. 1519, 2003.

[4] D. R. Kashyap, K. S. Dadhich, and S. K. Sharma, "Biomethanation under psychrophilic conditions: a review," Bioresource Technology, vol. 87, no. 2, pp. 147-153, 2003.

[5] Q. Li, L. Li, T. Rejtar, D. J. Lessner, B. L. Karger, and J. G. Ferry, "Electron transport in the pathway of acetate conversion to methane in the marine archaeon Methanosarcina acetivorans," Journal of Bacteriology, vol. 188, no. 2, pp. 702-710, 2006.

[6] J. G. Ferry and D. J. Lessner, "Methanogenesis in marine sediments," Annals of the New York Academy of Sciences, vol. 1125, pp. 147-157, 2008.

[7] M. S. M. Jetten, A. J. M. Stams, and A. J. B. Zehnder, "Methanogenesis from acetate: a comparison of the acetate metabolism in Methanothrix soehngenii and Methanosarcina spp," FEMS Microbiology Letters, vol. 88, no. 3-4, pp. 181-197, 1992.

[8] I. H. Franke-Whittle, B. A. Knapp, J. Fuchs, R. Kaufmann, and H. Insam, "Application of COMPOCHIP microarray to investigate the bacterial communities of different composts," Microbial Ecology, vol. 57, no. 3, pp. 510-521, 2009.

[9] C. Lee, J. Kim, K. Hwang, V. O’Flaherty, and S. Hwang, "Quantitative analysis of methanogenic community dynamics in three anaerobic batch digesters treating different wastewaters," Water Research, vol. 43, no. 1, pp. 157-165, 2009.
[10] M. Lee, T. Hidaka, W. Hagiwara, and H. Tsuno, "Comparative performance and microbial diversity of hyperthermophilic and thermophilic co-digestion of kitchen garbage and excess sludge," Bioresource Technology, vol. 100, no. 2, pp. 578-585, 2009.

[11] S. G. Shin, S. Lee, C. Lee, K. Hwang, and S. Hwang, "Qualitative and quantitative assessment of microbial community in batch anaerobic digestion of secondary sludge," Bioresource Technology, vol. 101, no. 24, pp. 9461-9470, 2010.

[12] S. Supaphol, S. N. Jenkins, P. Intomo, I. S. Waite, and A. G. O'Donnell, "Microbial community dynamics in mesophilic anaerobic co-digestion of mixed waste," Bioresource Technology, vol. 102, no. 5, pp. 4021-4027, 2011.

[13] D. Karakashev, D. J. Batstone, and I. Angelidaki, "Influence of environmental conditions on methanogenic compositions in anaerobic biogas reactors," Applied and Environmental Microbiology, vol. 71, no. 1, pp. 331-338, 2005.

[14] D. J. Aceti and J. G. Ferry, "Purification and characterization of acetate kinase from acetate-grown Methanosarcina thermophila. Evidence for regulation of synthesis," Journal of Biological Chemistry, vol. 263, no. 30, pp. 15444-15448, 1988.

[15] L. L. Lundie and J. G. Ferry, "Activation of acetate by Methanosarcina thermophila. Purification and characterization of phosphotransacetylase," Journal of Biological Chemistry, vol. 264, no. 31, pp. 18392-18396, 1989.

[16] H. P. E. Kohler and A. J. B. Zehnder, "Carbon monoxide dehydrogenase and acetate thiokinase in Methanothrix soehngenii," FEMS Microbiology Letters, vol. 21, no. 3, pp. 287-292, 1984.

[17] P. Pellerin, B. Gruson, G. Prensier, G. Albagnac, and P. Debeire, "Glycogen in Methanothrix," Archives of Microbiology, vol. 146, no. 4, pp. 377-381, 1987.

[18] M. S. M. Jetten, A. J. M. Stams, and A. J. B. Zehnder, "Isolation and characterization of acetyl-coenzyme A synthetase from Methanothrix soehngenii," Journal of Bacteriology, vol. 171, no. 10, pp. 5430-5435, 1989.

[19] M. T. Latimer and J. G. Ferry, "Cloning, sequence analysis, and hyperexpression of the genes encoding phosphotransacetylase and acetate kinase from Methanosarcina thermophila," Journal of Bacteriology, vol. 175, no. 21, pp. 6822-6829, 1993.

[20] J. G. Ferry, "Methane from acetate," Journal of Bacteriology, vol. 174, no. 17, pp. 5489-5495, 1992.

[21] K. C. Terlesky and J. G. Ferry, "Ferredoxin requirement for electron transport from the carbon monoxide dehydrogenase complex to a membrane-bound hydrogenase in acetate-grown Methanosarcina thermophila," Journal of Biological Chemistry, vol. 263, no. 9, pp. 4075-4079, 1988.

[22] G. W. J. Allen and S. H. Zinder, "Methanogenesis from acetate by cell-free extracts of the thermophilic acetotrophic methanogen Methanothrix thermophila CALS-1," Archives of Microbiology, vol. 166, no. 4, pp. 275-281, 1996.

[23] K. S. Smith and C. Ingram-Smith, "Methanosaeta, the forgotten methanogen?" Trends in Microbiology, vol. 15, no. 4, pp. 150-155, 2007.

[24] C. Welte and U. Deppenmeier, "Membrane-bound electron transport in Methanosaeta thermophila," Journal of Bacteriology, vol. 193, no. 11, pp. 2868-2870, 2011.

[25] M. S. M. Jetten, T. J. Fluit, A. J. M. Stams, and A. J. B. Zehnder, "A fluoride-insensitive inorganic pyrophosphatase isolated from Methanothrix soehngenii," Archives of Microbiology, vol. 157, no. 3, pp. 284-289, 1992.

[26] F. Ausubel, R. Brent, and R. Kingston, Current Protocols in Molecular Biology, John Wiley \& Sons, Brooklyn, NY, USA, 1987. 
[27] D. Hanahan, "Studies on transformation of Escherichia coli with plasmids," Journal of Molecular Biology, vol. 166, no. 4, pp. 557-580, 1983.

[28] J. E. Mott, R. A. Grant, Y. S. Ho, and T. Platt, "Maximizing gene expression from plasmid vectors containing the $\lambda \mathrm{P}(\mathrm{L})$ promoter: strategies for overproducing transcription termination factor $\rho$," Proceedings of the National Academy of Sciences of the United States of America, vol. 82, no. 1, pp. 88-92, 1985.

[29] U. K. Laemmli, "Cleavage of structural proteins during the assembly of the head of bacteriophage T4," Nature, vol. 227, no. 5259, pp. 680-685, 1970.

[30] H. Blum, H. Beier, and H. J. Gross, "Improved silver staining of plant proteins, RNA and DNA in polyacrylamide gels," Electrophoresis, vol. 8, no. 2, pp. 93-99, 1987.

[31] S. Saheki, A. Takeda, and T. Shimazu, "Assay of inorganic phosphate in the mild $\mathrm{pH}$ range, suitable for measurement of glycogen phosphorylase activity," Analytical Biochemistry, vol. 148, no. 2, pp. 277-281, 1985.

[32] Y. Meng, C. Ingram-Smith, L. L. Cooper, and K. S. Smith, "Characterization of an archaeal medium-chain acyl coenzyme A synthetase from Methanosarcina acetivorans," Journal of Bacteriology, vol. 192, no. 22, pp. 5982-5990, 2010.

[33] Y. Kuang, N. Salem, F. Wang, S. J. Schomisch, V. Chandramouli, and Z. Lee, "A colorimetric assay method to measure acetylCoA synthetase activity: application to woodchuck model of hepatitis virus-induced hepatocellular carcinoma," Journal of Biochemical and Biophysical Methods, vol. 70, no. 4, pp. 649655, 2007.

[34] H. Brüggemann, F. Falinski, and U. Deppenmeier, "Structure of the $\mathrm{F}_{420} \mathrm{H}_{2}$ :quinone oxidoreductase of Archaeoglobus fulgidus identification and overproduction of the $\mathrm{F}_{420} \mathrm{H}_{2}$ oxidizing subunit," European Journal of Biochemistry, vol. 267, no. 18, pp. 5810-5814, 2000.

[35] S. Bäumer, S. Lentes, G. Gottschalk, and U. Deppenmeier, "Identification and analysis of proton-translocating pyrophosphatases in the methanogenic archaeon Methansarcina mazei," Archaea, vol. 1, no. 1, pp. 1-7, 2002.

[36] J. W. Scott, S. A. Hawley, K. A. Green et al., "CBS domains form energy-sensing modules whose binding of adenosine ligands is disrupted by disease mutations," The Journal of Clinical Investigation, vol. 113, no. 2, pp. 274-284, 2004.

[37] S. Meyer, S. Savaresi, I. C. Forster, and R. Dutzler, "Nucleotide recognition by the cytoplasmic domain of the human chloride transporter ClC-5," Nature Structural \& Molecular Biology, vol. 14, no. 1, pp. 60-67, 2007.

[38] B. E. Kemp, "Bateman domains and adenosine derivatives form a binding contract," The Journal of Clinical Investigation, vol. 113, no. 2, pp. 182-184, 2004.

[39] S. Ahn, A. J. Milner, K. Fütterer et al., "The "open" and "closed" structures of the type-C inorganic pyrophosphatases from Bacillus subtilis and Streptococcus gordonii," Journal of Molecular Biology, vol. 313, no. 4, pp. 797-811, 2001.

[40] M. C. Merckel, I. P. Fabrichniy, A. Salminen et al., "Crystal structure of Streptococcus mutans pyrophosphatase: a new fold for an old mechanism," Structure, vol. 9, no. 4, pp. 289-297, 2001.

[41] J. Jämsen, H. Tuominen, A. Salminen et al., "A CBS domaincontaining pyrophosphatase of Moorella thermoacetica is regulated by adenine nucleotides," Biochemical Journal, vol. 408, no. 3, pp. 327-333, 2007.

[42] J. M. Davies, R. J. Poole, P. A. Rea, and D. Sanders, "Potassium transport into plant vacuoles energized directly by a protonpumping inorganic pyrophosphatase," Proceedings of the
National Academy of Sciences of the United States of America, vol. 89, no. 24, pp. 11701-11705, 1992.

[43] P. E. Jablonski, A. A. DiMarco, T. A. Bobik, M. C. Cabell, and J. G. Ferry, "Protein content and enzyme activities in methanoland acetate-grown Methanosarcina thermophila," Journal of Bacteriology, vol. 172, no. 3, pp. 1271-1275, 1990.

[44] K. Singh-Wissmann and J. G. Ferry, "Transcriptional regulation of the phosphotransacetylase-encoding and acetate kinase-encoding genes (pta and ack) from Methanosarcina thermophila," Journal of Bacteriology, vol. 177, no. 7, pp. 16991702, 1995.

[45] U. Deppenmeier, A. Johann, T. Hartsch et al., "The genome of Methanosarcina mazei: evidence for lateral gene transfer between bacteria and archaea," Journal of Molecular Microbiology and Biotechnology, vol. 4, no. 4, pp. 453-461, 2002.

[46] R. D. Barber, L. Zhang, M. Harnack et al., "Complete genome sequence of Methanosaeta concilii, a specialist in aceticlastic methanogenesis," Journal of Bacteriology, vol. 193, no. 14, pp. 3668-3669, 2011.

[47] C. Ingram-Smith, B. I. Woods, and K. S. Smith, "Characterization of the acyl substrate binding pocket of acetyl-CoA synthetase," Biochemistry, vol. 45, no. 38, pp. 11482-11490, 2006.

[48] Y. L. Teh and S. H. Zinder, "Acetyl-coenzyme A synthetase in the thermophilic, acetate-utilizing methanogen Methanothrix sp. strain CALS-1," FEMS Microbiology Letters, vol. 98, no. 1-3, pp. 1-7, 1992.

[49] N. J. Kuhn, A. Wadeson, S. Ward, and T. W. Young, "Methanococcus jannaschii ORF mj0608 codes for a class $\mathrm{C}$ inorganic pyrophosphatase protected by $\mathrm{Co}^{2+}$ or $\mathrm{Mn}^{2+}$ ions against fluoride inhibition," Archives of Biochemistry and Biophysics, vol. 379, no. 2, pp. 292-298, 2000.

[50] B. Siebers and R. Hensel, "Pyrophosphate-dependent phosphofructokinase from Thermoproteus tenax," Methods in Enzymology, vol. 331, pp. 54-62, 2001.

[51] A. S. Reshetnikov, O. N. Rozova, V. N. Khmelenina et al., "Characterization of the pyrophosphate-dependent 6-phosphofructokinase from Methylococcus capsulatus Bath," FEMS Microbiology Letters, vol. 288, no. 2, pp. 202-210, 2008.

[52] V. N. Khmelenina, O. N. Rozova, and Y. A. Trotsenko, "Characterization of the recombinant pyrophosphate-dependent 6phosphofructokinases from Methylomicrobium alcaliphilum $20 \mathrm{Z}$ and Methylococcus capsulatus Bath," Methods in Enzymology, vol. 495, pp. 1-14, 2011.

[53] Z. Deng, D. Roberts, X. Wang, and R. G. Kemp, "Expression, characterization, and crystallization of the pyrophosphatedependent phosphofructo-1-kinase of Borrelia burgdorferi," Archives of Biochemistry and Biophysics, vol. 371, no. 2, pp. 326-331, 1999.

[54] I. Bruchhaus, T. Jacobs, M. Denart, and E. Tannich, "Pyrophosphate-dependent phosphofructokinase of Entamoeba histolytica: molecular cloning, recombinant expression and inhibition by pyrophosphate analogues," Biochemical Journal, vol. 316, no. 1, pp. 57-63, 1996.

[55] B. Tjaden, A. Plagens, C. Dörr, B. Siebers, and R. Hensel, "Phosphoenolpyruvate synthetase and pyruvate, phosphate dikinase of Thermoproteus tenax: key pieces in the puzzle of archaeal carbohydrate metabolism," Molecular Microbiology, vol. 60, no. 2, pp. 287-298, 2006.

[56] R. E. Reeves, "Pyruvate,phosphate dikinase from Bacteroides symbiosus," Biochemical Journal, vol. 125, no. 2, pp. 531-539, 1971. 
[57] N. Eisaki, H. Tatsumi, S. Murakami, and T. Horiuchi, "Pyruvate phosphate dikinase from a thermophilic actinomyces Microbispora rosea subsp. aerata: purification, characterization and molecular cloning of the gene," Biochimica et Biophysica Acta, vol. 1431, no. 2, pp. 363-373, 1999. 

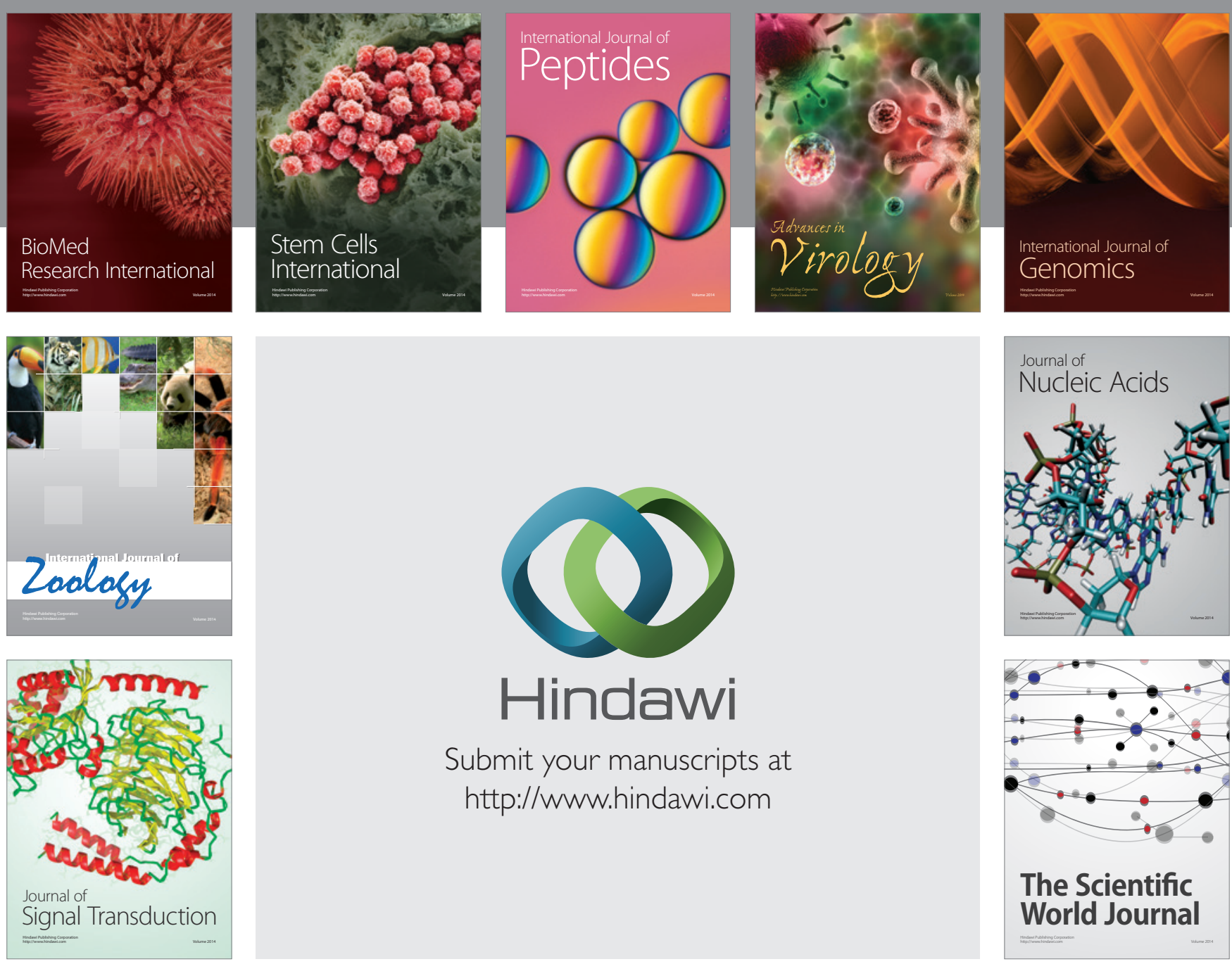

Submit your manuscripts at

http://www.hindawi.com
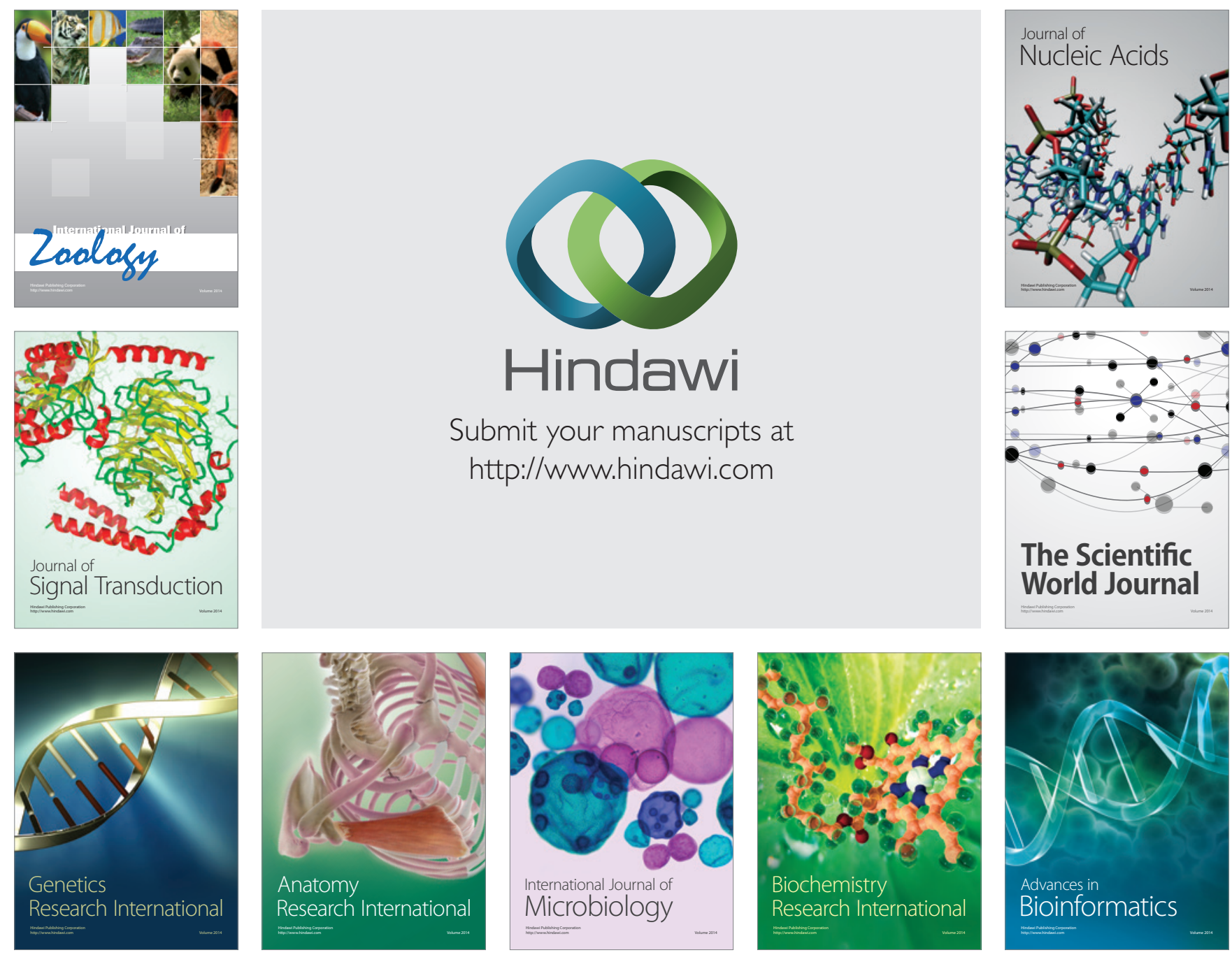

The Scientific World Journal
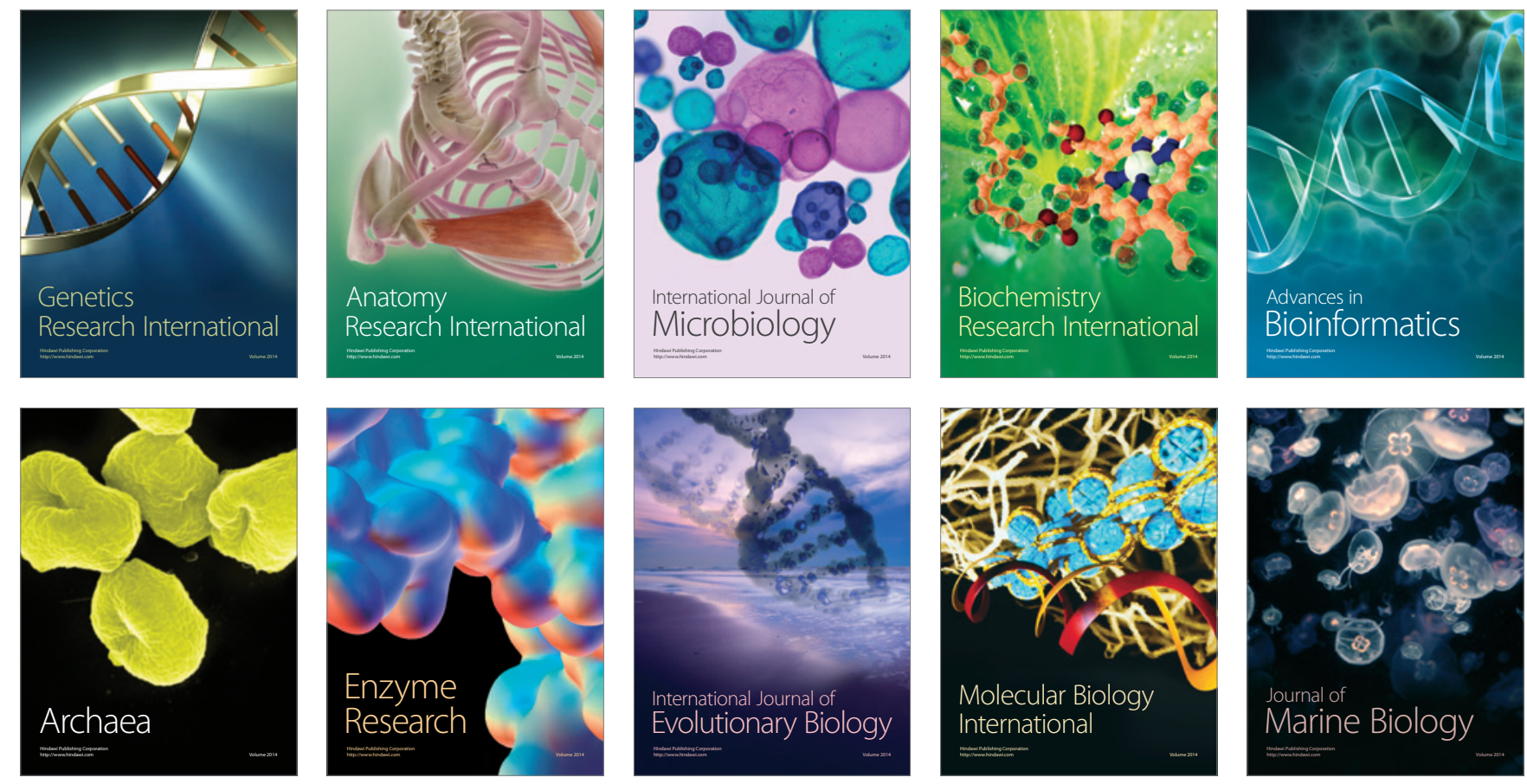